\title{
Nuclear genome size variation in the allopolyploid Onosma arenaria-0. pseudoarenaria species group: Methodological issues and revised data
}

\begin{tabular}{|r|l|}
\hline Journal: & Botany \\
\hline Manuscript ID & cjb-2017-0164.R2 \\
\hline Manuscript Type: & Article \\
\hline Date Submitted by the Author: & O6-Feb-2018 \\
\hline Complete List of Authors: & $\begin{array}{l}\text { Kolarčik, Vladislav; P. J. Šafárik University, Institute of Biology and } \\
\text { Ecology, Faculty of Science } \\
\text { Kocová, Valéria; P. J. Šafárik University, Institute of Biology and Ecology, } \\
\text { Faculty of Science } \\
\text { Caković, Danka; University of Montenegro, Faculty of Natural Sciences and } \\
\text { Mathematics, Department of Biology } \\
\text { Kačmárová, Tatiana; - } \\
\text { Piovár, Juraj; - } \\
\text { Mártonfi, Pavol; P. J. Šafárik University, Institute of Biology and Ecology, } \\
\text { Faculty of Science }\end{array}$ \\
\hline Is the invited manuscript for \\
consideration in a Special \\
Issue? :
\end{tabular}


Nuclear genome size variation in the allopolyploid Onosma arenaria-O. pseudoarenaria species group: Methodological issues and revised data

V. KolarČIK ${ }^{* 1}$, V. KocovÁ ${ }^{1}$, D. CAKOVIĆ ${ }^{2}$, T. KAČMÁROVÁ ${ }^{3}$, J. PIOVÁR $^{4}$ and P. MÁRTONFi ${ }^{1}$

${ }^{1}$ Institute of Biology and Ecology, Faculty of Science, P. J. Šafárik University, Mánesova 23, SK-04154 Košice, Slovak Republic

${ }^{2}$ Department of Biology, Faculty of Natural Sciences and Mathematics, University of Montenegro, Džordža Vašingtona bb, ME-810 00 Podgorica, Montenegro

${ }^{3}$ Vagrinec 18, SK-090 03 Ladomirová, Slovak Republic

${ }^{4}$ Raketova 9/1473, SK-040 12 Košice, Slovak Republic

\footnotetext{
* Author responsible for correspondence: Vladislav Kolarčik; phone: + 42155 2342318; fax: + 42155 6337353; e-mail: vladislav.kolarcik@upjs.sk
} 


\begin{abstract}
:
We used flow cytometry (FCM) to investigate genome size variation in two polymorphic allopolyploids, Onosma arenaria and O. pseudoarenaria, in Central Europe and the Balkan Peninsula. An intercalating DNA stain, propidium iodide (PI), and internal standardization were used. Our data showed that cytosolic compounds may be present in FCM samples and could inhibit, or more frequently promote, PI intercalation. In the absence of PI intercalation interference, leaf-based genome size estimates were observed to be lower than seed-based ones in $O$. pseudoarenaria, whereas no difference was recorded in $O$. arenaria. In incubation tests genome size values frequently increase after a longer staining period. For final genome size measurements, we applied the FCM protocol based on seed material using a $\sim 150$-min incubation period, and provide evidence of mean genome size variation among populations of both species. Two and four natural genome size groups were revealed in $O$. arenaria and $O$. pseudoarenaria respectively. Group mean genome sizes varied considerably in both $O$. arenaria (5.36-5.76 pg) and $O$. pseudoarenaria (5.98-6.58 pg). This extensive genome size variation is attributed to unexplored taxonomic heterogenity in both taxa. Future taxonomic revision of the group may be supported with genome size measurements obtained using an appropriately standardized methodology.
\end{abstract}

Keywords: flow cytometry, genome size, incubation test, inhibition test, seed material 


\section{Introduction}

Systematists use various approaches to describe biological diversity and to delimit living organic units as certain taxa. Studies of morphological and anatomical variation, niche differentiation, reproduction systems, variation in secondary metabolites, and characterization of chromosome sets and genome as well as DNA molecular variation are some of the most utilized in plant systematics (Simpson 2010; Stuessy et al. 2014; Judd et al. 2016). In the early 1990s, a method for rapid DNA content estimation based on flow cytometry (FCM) analysis of the optical features of isolated and stained cell nuclei was introduced for use in plant systematic studies (Galbraith et al. 1983; Otto et al. 1990; Doležel and Göhde 1995; Doležel et al. 2007; Greilhuber et al. 2007). Intraspecific genome size variation can be interpreted as an indicator of taxonomic heterogeneity (Murray 2005), and indeed, the method soon became routinely used in taxonomy as a key or supplementary method to delimit particular taxa (Suda et al. 2007b; Zonneveld 2009; Loureiro et al. 2010). This technique has been most informative in taxonomic studies of plant groups where particular taxa with shallow morphological differentiation are characterized by the same chromosome number and are not sufficiently diversified to show significantly different structured karyological and cytogenetic patterns (Zonneveld 2009; Loureiro et al. 2010; Angulo and Dematteis 2013; Chalup et al. 2014). Moreover, rough estimations of genome size are helpful to determine ploidy level, which is an important organismal feature in ecological, evolutionary, and systematic studies (Knight et al. 2005; Suda et al. 2007b).

Estimation of genome size using FCM has been successfully applied in many plant groups, including non-vascular plants (Volgmayr 2007; Bainard and Newmaster 2010), pteridophytes (Obermayer et al., 2002), gymnosperms (Murray 1998; Hall et al. 2000; Zonneveld 2012a, 2012b), and many angiosperms (Garcia et al. 2014). There are, however, 
numerous groups that are difficult to study using FCM, due to difficulties in nuclei isolation (Doležel and Bartoš 2005), presence of secondary metabolites (Price et al. 2000; Pinto et al. 2004; Doležel and Bartoš 2005; Greilhuber 2007; Cires et al. 2011) or low resistance of material to damage caused by long-term preservation (Doležel and Bartoš 2005). The family Boraginaceae is among the least well studied plant groups, although the reasons in this case are not well known. The presence of secondary metabolites or their low interest among botanists may be causal (Suda 2004). To date, Boraginaceae, which comprises approximately 1600-1700 species (Chacón et al. 2016), has been represented by only 35 FCM estimates of genome size in the Angiosperm DNA C-values database (Bennett and Leitch 2012), which corresponds to only $\sim 2 \%$ of the species within the family. Thus, the potential use of FCM in the systematic study of this family and particular genera is an open question. To illustrate the rarity and importance of genome size studies within Boraginaceae, Suda et al. (2005) studied several species of Echium and observed high genome size variations among taxa, some of which were well delimited based on genome size data despite possessing the same chromosome number. These data represent more than a third of all published FCM estimates within the Boraginaceae family.

One of the most species-rich and diversified genera of Boraginaceae is the genus Onosma L. (Chacón et al. 2016). Species of Onosma inhabit dry, xerothermic, and typically stony habitats in regions of the Mediterranean basin and Near East, but are also distributed in steppic, karstic, and mountain regions in Central Europe, Central Asia, and the southern foothills of the Himalayas (Jávorka 1906; Meusel et al. 1978). This group is very variable in terms of karyology, and includes diploids and polyploids with basic chromosome numbers of $\mathrm{x}=6,7,8,910$, and 11 (Luque 1990). Moreover, the genus also contains certain allopolyploid taxa that combine at least two genomes of different basic numbers. Although the basic phylogenetic relationships among taxa of the genus have yet to be clarified, 
hybridization and polyploidization seem to be important forces promoting genus differentiation (Kolarčik et al. 2010, 2014, 2015). This is exemplified in Europe by one of three infrageneric groups, Heterotricha. In this group, evolutionary processes have resulted in polymorphism and probably the most widely occurring taxa of the genus in Europe, $O$. arenaria Waldst. \& Kit. (in the wide sense, for simplicity hereafter referred to as O. arenaria) and $O$. pseudoarenaria Schur (in the wide sense, referred to as O. pseudoarenaria). Their hybrid origins are suggested mainly based on karyological (Teppner 1971) and molecular data (Kolarčik et al. 2014). Both groups are morphologically complex, with up to 16 different taxa recognized at the species or infraspecific level (Ball 1972; Rauschert 1976; Vouillamoz 2001). To date, this complex variation has yet to be explored in detail and taxonomic misidentifications are very common (Ball 1972). In recent studies, these groups have generally been accepted as two complex species in the wide sense (Mártonfi et al. 2008; Kolarčik et al. 2010; Kolarčik et al. 2014). Both species contain genomes with specific karyological features, and have combinations of large (L) and small (S) chromosomes that probably originated from descendants with uniform "L" or "S" genomes. Genome size has been investigated to a limited extent in both species; however, studies have indicated that there is considerable variability in genome size among populations even though the species are cytologically uniform (Kolarčik et al. 2014; Kolarčik et al. unpublished data). Populations of $O$. arenaria and $O$. pseudoarenaria show $2 \mathrm{n}=12 \mathrm{~L}+8 \mathrm{~S}$ and $2 \mathrm{n}=12 \mathrm{~L}+14 \mathrm{~S}$, respectively. Sporadically, B chromosomes have been observed in their karyotypes (Mártonfi et al. 2008; Kolarčik et al. 2014). Exploration of genome size in these groups is very timely and relevant for taxonomic, cytogenetic or genome evolution studies.

Although a thorough examination of genome size may elucidate several evolutionary or taxonomic issues within the Onosma genus, the DNA content has been determined in very few taxa (eight taxa in four different studies, Mártonfi et al. 2008; Siljak-Yakovlev et al. 
2010; Kolarčik et al. 2014; Kolarčik et al. 2015). However, although high variability has been observed even within single species, we can not exclude the possibility that this variation could be an artefact caused by methodological errors. Secondary metabolites present in several taxa of the genus (Ding et al. 2004; Mazandarani et al. 2011; Mazandarani et al. 2012; Sun et al. 2007; Wu et al. 2009; Gharib and Godarzee 2016; Sut et al. 2017) may be responsible for several factors that have been reported in genome size studies, such as inhibition (Price et al. 2000) or incubation (Bainard et al. 2010) effects. Despite the several pitfalls in genome size studies, the problems associated with methodological issues are rarely reported (Bainard et al. 2010; Wang et al. 2015). In this regard, to overcome problems associated with nuclei isolation arising from the presence of secondary metabolites in the organs of mature plants, Sliwinska et al. (2005) proposed seed material as a source for the isolation of nuclei in FCM-based genome size studies. However, seeds also contain various metabolites that may interfere with DNA staining substances (Naczk et al. 1998). Furthermore, some authors do not recommend the use of seed material to infer genome size because seeds may exhibit a different range of genome size compared with mature plants, which have undergone selective processes (Šmarda et al. 2010).

Here, we explore various aspects of the FCM technique, and by employing an improved FCM protocol, we determine the genome sizes in various populations of $O$. arenaria and O. pseudoarenaria distributed in Central Europe and the Balkan Peninsula, and where possible, compare the results obtained from seed material with those obtained using leaf material.

Our specific aims were as follows:

i) to verify the effects of potential cytosolic inhibitors on FCM measurements;

ii) to explore the effects of duration of sample incubation with PI on FCM measurements; 
iii) to estimate the rough error of the FCM protocol applied; and

iv) to determine nuclear genome size for various populations and infraspecific taxa of O. arenaria and $O$. pseudoarenaria in Central Europe and Balkan Peninsula.

\section{Material and Methods}

\section{Plant material}

Representative individuals of $O$. arenaria and $O$. pseudoarenaria originating from five and 14 populations, respectively (Fig. 1, Table 1) were collected and their leaf or seed material was used in all subsequent analyses.

Onosma arenaria is treated here as a single species and investigated populations were assigned to O. arenaria subsp. arenaria. Although Onosma pseudoarenaria is here accepted as a single species, several infraspecific taxa are recognized in the Balkan region and Central Europe. Here, sampled populations were identified as O. pseudoarenaria subsp. austriaca (Beck) Dostál, O. pseudoarenaria subsp. fallax (Borb.) Rauschert, O. pseudoarenaria subsp. pseudoarenaria, and O. pseudoarenaria subsp. tuberculata (Kit.) Rauschert. For one population, we were unable to assign a subspecific status and thus the status of this population was treated as uncertain.

\section{Sample preparation for flow cytometry genome size measurements}

FCM genome size estimation and all experiments designed to determine the methodological limitations of the FCM procedure were performed using a Partec CyFlow ML flow cytometer (Partec Gmbh, Münster, Germany) at the Institute of Biological and Ecological Sciences, P. J. Šafárik University, Košice (Slovakia). The device is equipped with 
a 532-nm laser beam operating at $150 \mathrm{~mW}$ and band pass $590-\mathrm{nm}$ optical filter. Sample preparation was the same as that described by Kolarčik et al. (2014), in which we applied a two-step procedure involving nuclei isolation and staining (Doležel and Göhde 1995), and internal standardization (Doležel et al. 2007). The specifications of sample preparation in experiments are described below. Propidium iodide (PI) was used as a DNA intercalating dye. As reference standards, we used Solanum pseudocapsicum L. $(2 \mathrm{C}=2.59 \mathrm{pg}$, Temsch et al. 2010) or S. lycopersicum L. cv. Stupnické polní tyčkové rané $(2 \mathrm{C}=1.96$ pg, Doležel et al. 1992). Nuclei isolation was performed in GPB buffer (Loureiro et al. 2007). FCM measurements were obtained using FloMax 2.70 software (Partec Gmbh, Münster, Germany) and histograms were analysed using FlowJo ver. 10.1 software (FlowJo LLC, Ashland, USA). Estimation of the DNA content in samples was based on values of the $G_{0} / G_{1}$ peak means according to the following formula: DNA content of sample (pg) = DNA content of used standard $(\mathrm{pg}) \times\left[\left(\mathrm{G}_{0} / \mathrm{G}_{1}\right.\right.$ peak mean of sample $) /\left(\mathrm{G}_{0} / \mathrm{G}_{1}\right.$ peak mean of standard $\left.)\right]$.

\section{Inhibition test to detect the presence of cytosolic compounds inhibiting PI intercalation}

The presence of staining inhibitors in nuclei isolates, sensu Price et al. (2000), was investigated for both leaf and seed samples. The principle of this test is based on detection of two reference standard peaks in simultaneous FCM analyses of mixed samples A + B, where A represents the sample of Onosma + reference standard co-processed (nuclei isolation and PI staining) together, and sample B contains only of the reference standard processed separately. Briefly, the internal reference standard (S. pseudocapsicum) was processed together with Onosma material (A sample) and individually (B sample). After staining for $30 \mathrm{~min}$, samples A and B were measured separately for PI fluorescence, mixed together immediately and measured again. The experiment was repeated for 22 plants and 30 seeds collected from nine populations. 
Effect of incubation time on propidium iodide fluorescence intensity

Samples for this test were prepared as described above together with the reference standard S. pseudocapsicum (or in few cases S. lycopersicum), stained, and then measured. Each sample used for FCM was prepared and stained once and then measured four times within 1 day after $30,90,150$, and 270 min of incubation. The experiment was repeated for 24 seeds collected from five populations. Genome size determinations within seeds were analysed and an appropriate incubation time was chosen for subsequent genome size determinations (see below).

Error rate estimation for the flow cytometry methodology: between-day variation

FCM between-day fluctuations in genome size estimates have been reported several times (e.g. Šmarda and Bureš 2006; Leong-Škorničková 2007; Suda et al. 2007a; Escudero et al. 2015; Dauphin et al. 2016). We therefore analysed the between-day stability of the FCM methodology applied in the present study. The seeds of Onosma species are typically small, and generally do not exceed $3 \mathrm{~mm}$ in length in most of the European species. Despite limited amounts of material, we divided Onosma seeds into three parts and each part was used in independent genome size measurements performed on three different days. Each part was processed together with a reference standard (S. pseudocapsicum), incubated for $150 \mathrm{~min}$ (determined based on incubation time effect experiment), and then measured. The average value of the three independent genome size measurements was calculated for each individual seed and measurement error rate was defined as the difference between a particular measurement and the "ideal" average value (Šmarda and Bureš 2006). Twenty-seven individual seeds were analysed in this experiment. 


\section{Sample preparation and genome size measurements}

Genome size was estimated using 394 individual seeds (including 27 seeds measured three times in the error rate determination experiment) originating from 85 individual plants of 19 populations. Each sample was processed with an internal reference standard $(S$. pseudocapsicum), incubated with PI for approximately $150 \mathrm{~min}$, and then measured. Genome size was calculated based on FCM histogram data according the formula given above.

Statistical analyses (tests of equal means or medians) were performed using Past ver. 3.15 software (Hammer et al. 2001) and R ver. 3.3.2 environment (R Development Core Team 2016), and figures were created using the ggplot2 ver. 2.2.1 package (Wickham 2009). Prior to statistical testing, the normality (Shapiro-Wilk test) and homoscedasticity (Levene`s test) of the data were verified.

\section{Results}

PI staining is affected by cytosolic compounds and incubation period

Although we detected PI intercalation inhibition, we more frequently recorded a promotion effect in several of the investigated samples (for examples, see Fig. 2). PI intercalation was affected more often in leaf $(68 \%)$ than in seed $(25 \%)$ samples (Table 2). Staining inhibition was recorded only sporadically in seed samples, but was absent in leaf samples. The staining promotion effect was recorded in both seed and leaf samples. Although the nature of the data does not allow for rigorous statistical testing, it is of interest to note that the data suggest that differences in staining intercalation are mostly dependent on individual plants or seeds. 
Overall, 24 seeds were subjected to the incubation test, although in one case we failed to complete four repeats (after 30,90, 150, and $270 \mathrm{~min}$ of incubation), and therefore only data for 23 seeds are presented. We almost always recorded an increase in relative genome size after 90 min when compared with measurements performed after 30 min of staining, the single exception being one population of $O$. arenaria (coded EPO). A further increase in mean genome size was recorded after an additional 60 minutes (at 150 min of incubation). After 150 min of staining, apparent saturation of PI intercalation was recorded in most of populations (Fig. 3). Results of the ANOVA indicated incubation period affected relative genome size $(p<0.001)$. The Tukey's pairwise post-hoc test did not reveal significant relative genome size difference between the 150 and 270 min incubation periods. This suggests that staining saturation was complete in most of the samples after $150 \mathrm{~min}$. This incubation period was applied in subsequent measurements.

\section{Error rate in flow cytometry analyses}

The differences between the minimal and maximal values measured per seed ranged between $1.41 \%$ and $6.67 \%$ (the average value is $3.79 \%$, Fig. $4 \mathrm{~A}$ ). Differences in genome size compared with the average value calculated from three independent estimates per seed expressed in percentage was considerable (Fig. 4b), the standard deviation reached up to $1.74 \%$ and the $5-95$ percentile was $-2.52 \%-2.81 \%$.

\section{Seed vs. leaf material}

On the basis of data obtained in the inhibition test, it was possible to compare differences in seed- and leaf-based FCM measurements of genome size. For this, we excluded measurements that showed an inhibition or promotion effect. Direct comparison showed that, in most cases, seed-based genome size estimates were higher than those based on leaves (Fig. 
5), whereas measurement quality standards (see Doležel et al. 2007) were always met [CV (\%) values were 1.7-4.5 (2.6 mean) and 1.9-4.5 (2.9 mean) for the standard and sample peak, respectively]. In comparison with the leaf-based FCM data, the mean genome size calculated from the seed-based FCM data was on average higher by $7.3 \%$ in $O$. pseudoarenaria $(6.00 \mathrm{pg}$ vs. $6.44 \mathrm{pg}$ ) and by $0.0 \%$ in O. arenaria (5.23 pg vs. $5.23 \mathrm{pg}$, Fig. 5). Furthermore, the difference between seed- and leaf-based data for population mean genome size values was significant for $O$. pseudoarenaria $(t=-3.79, p<0.001)$, although not for $O$. arenaria $(t=$ $0.014, p=0.99)$.

Genome size of Onosma arenaria and O. pseudoarenaria in Central Europe and the Balkan Peninsula

Genome size was estimated for five taxa and a total of 19 populations, which can be assigned to eight groups based on taxonomy, cytology, and geography. Examples of FCM histograms are depicted in Fig. 6. Most of the values fall close to the population average, with the exception of six values, all recorded from $O$. pseudoarenaria ssp. fallax. Three seeds having $\sim 9.5$ pg DNA are interpreted as allohexaploids, whereas two seeds having $\sim 4.5 \mathrm{pg}$ DNA are interpreted as potential allotriploids, and one seed with $\sim 3$ pg DNA is probably diploid. The data for these samples were omitted in further population/group mean calculations. Other measurements (19 in total) appeared as outliers (Fig. 7) and may represent seeds with abnormal chromosome complements.

In O. pseudoarenaria, the population mean values differed (Kruskal-Wallis test, $p<$ 0.001 ) and varied from $5.98 \mathrm{pg}$ to $6.63 \mathrm{pg}$ (Table 1). With the exception of $O$. pseudoarenaria subsp. fallax, population mean genome size values within taxa were not highly variable. Populations of this taxon were sampled from Dalmatia (Croatia) and southwestern Balkans (Bosnia and Herzegovina + Montenegro) (Fig. 1). When the data were analysed with respect 
to taxonomic assignment with the exception of $O$. pseudoarenaria subsp. fallax, which was divided into two groups according to their geographical origin (HR and $\mathrm{BA}+\mathrm{ME})$, mean genome sizes differed between groups (Kruskal-Wallis test, $p<0.001$, Fig. 7). Mean genome size values were $5.98 \mathrm{pg}$ in $O$. pseudoarenaria subsp. austriaca, $6.58 \mathrm{pg}$ in $O$. pseudoarenaria subsp. fallax (HR), $6.31 \mathrm{pg}$ in O. pseudoarenaria subsp. fallax (BA $+\mathrm{ME}), 6.34 \mathrm{pg}$ in $O$. pseudoarenaria subsp. pseudoarenaria, and 6.19 pg in $O$. pseudoarenaria subsp. tuberculata (Table 1, Fig. 7).

Onosma arenaria is represented here by a single taxon, $O$. arenaria subsp. arenaria. However, population mean genome size values differed between populations (Kruskal-Wallis test, $p<0.001$, Table 1). Again, apparent differentiation was seen between groups of populations from Central Europe + Romania and populations from Dalmatia (Croatia, Table 1, Fig. 7). When the data were further pooled according geographic region, mean genome sizes differed between both groups of populations within a single taxon (Mann-Whitney test, $p<0.001$, Fig. 7)

\section{Discussion}

Nuclear DNA content estimation is one of the most important applications of FCM in the plant sciences (Doležel et al. 2007; Greilhuber et al. 2007; Suda et al. 2007b). Considerable amounts of genome size data for representative taxa are necessary to study the biological role of DNA content in the cell. To date, the genome sizes of only $2.1 \%$ of angiosperm species have been characterized (Garcia et al. 2014). Furthermore, although several studies have shown that genome size is species-stable, exceptions have also been found. This variation could be attributed to recent hybridization, unrevealed cryptic species differences, or recent diversification processes (Zonneveld 2009; Ceccarelli et al. 2011; 
Hanušová et al. 2014). Understanding the consequences of variation in this cytological feature may be useful in many ecological- and evolutionary-focused studies (Leitch and Bennett 2007).

In the group Heterotricha of the genus Onosma, hybridization is suggested as an important evolutionary process and speciation mode acting within the European range of this group (Kolarčik et al. 2014), leading to the origin of novel entities, which have long been recognized as separate taxa. Previously, differentiated new species showing intermediate hybrid character states have been described, most of which were later subsumed into $O$. pseudoarenaria and O. arenaria at the subspecific level (Rauschert et al. 1976). Nevertheless, taxonomic relationships are still not satisfactorily clarified, with misidentifications often persisting and taxa being determined based on geographic origin rather than by morphological differences. Even basic consensus on the question of whether taxa should be treated at the specific or subspecific level is lacking in some cases. Not surprisingly, groups are treated as two species in a wide sense, $O$. arenaria and $O$. pseudoarenaria. In light of a recent study suggesting the multiple origin of $O$. arenaria (Kolarčik et al. 2014), critical taxonomic reevaluation of both plant groups is urgently needed. The disentangling of this taxonomically problematic group may be achieved to some extent by using genome size data. A further application of genome size in this respect is the precise assessment of the genomic constitution of allopolyploid genomes (Doležel et al. 2007), which is one of the key aims of cytogenetic research. However, relevant comparison of FCM genome size data in the genus Onosma would not be possible without appropriately standardized FCM measurements. Accordingly, in the present study, we have proposed an appropriate FCM protocol based on seed source material for clarifying certain problematic issues regarding sample preparation for FCM. 
Previous reports have indicated the presence of considerable genome size variation in O. arenaria and O. pseudoarenaria (Mártonfi et al. 2008; Kolarčik et al. 2014). However, the genome size estimates in these studies were based on leaf material, and certain methodological issues were not considered. Several studies have re-evaluated previous reports on the presence of infraspecific genome size variation in plants and concluded that this variation is due to artefacts of methodological origin, including different laboratory conditions, lack of internal standardization, the presence of stain intercalation inhibiting compounds or tannic acid promoted coatings of debris to the nuclei (Price et al. 2000; Noirot et al. 2000; Greilhuber 2005; Loureiro et al. 2006; Bennett et al. 2008). Although plant material should routinely be tested for the presence of cytosolic inhibiting compounds, this practice is rarely reported in genome size studies. Secondary metabolites are commonly present in the family Boraginaceae (Papageorgiou et al. 1999), and aliphatic ketones, lipids, naphthazarins, alkaloids, phenolics, flavones, and naphthoquinones have been found in the genus Onosma (Kumar et al. 2013). These compounds may potentially interfere with PI intercalation into DNA. A stain intercalation inhibition test is therefore reasonable in this case. In the present study, we determined the effect of inhibiting compounds in $O$. arenaria and $O$. pseudoarenaria, but frequently observed a stain promotion effect. On the basis of our observations, the levels of compounds interfering with stain intercalation appear to differ among individuals. Alternatively, the inhibition effect may be caused by the aggregation of minor particles with nuclei that may also affect fluorescence intensity (Loureiro et al. 2006; Greilhuber et al. 2007). This is accompanied by the low quality of FCM histograms, which may be the case in some tested samples (Fig. 2). Given such a variable plant system, if genome size estimates are based on leaf material of a few individuals, contradictory results may easily be obtained. 
To avoid the potential problems associated with the presence of secondary metabolites in leaves, Sliwinska et al. (2005) suggested the use of seeds as a source material for genome size estimations. This approach has already been successfully applied in the study of genome size in some angiosperms (Jedrzejczyk and Sliwinska 2010; Šarhanová et al. 2012). Here, we show that even though seed material is not free of cytosolic compounds, the interference effect is less prominent than in leaves (Table 2). Accordingly, it appears that seeds could be potentially more useful then leaves in genome size determinations in the genus Onosma. Nevertheless, the reliability of genome size data based on seed material has been criticized, because the seeds of individual plants can be cytologically heterogeneous, including aneuploids or euploids with extremely low or high genome size, and that the plants resulting from such seeds are very probably selectively eliminated during the early seedling stage (Šmarda et al. 2010). However, in carefully designed studies, the population mean genome size does not depend on material type, with cytologically heterogeneous seeds and more homogeneous mature plants showing similar mean genome sizes (Šmarda et al. 2010). Our data are therefore sufficiently representative and we are confident that seed material can be reliably used to study genome size variability in the genus Onosma at the population level.

Our comparison of leaf-based and seed-based FCM estimates showed different patterns in $O$. pseudoarenaria and $O$. arenaria. Although we were unable to detect any significant difference between leaf-based and seed-based FCM estimates in O. arenaria, in $O$. pseudoarenaria, the population mean genome size was always higher in seeds. This suggests that interference by cytosolic compounds is only one of the factors that could potentially affect genome size estimates in Onosma. The lower quality of FCM histograms in leaf-based samples, which may result in higher $\mathrm{CV}$ values, is not considered to be responsible for the 
seed- vs. leaf-based genome size differences observed in the present study. The CV values for both leaf- and seed-based FCM measurements was below 5\% (see Results section). A further factor that might account for the variable measurements is the different tissue-specific level of DNA condensation (Biradar and Lane Rayburn 1994); however, it is not believed that this is the reason for the variation in genome size based on FCM measurements (see Sliwinska et al. 2005). Indeed, extensive changes in genome architecture during seed maturation and seedling establishment have previously been reported (van Zanten et al. 2011; Borbousse et al. 2015); however, their effect on genome size was not investigated. Hence, the factor(s) responsible for this issue remains unclear and warrant further research.

In addition to the interference effect of cytosolic compounds on PI intercalation, staining duration may have also unintentional effect on genome size estimates. We have shown that an increase in staining duration may result in an apparent increase in genome size in Onosma. A similar effect has previously been reported in mosses (Bainard et al. 2010) and some angiosperms (Wang et al. 2015). Therefore, sample staining procedure should be improved and exact incubation times defined. In the present study, all samples were incubated with PI for $\sim 2.5$ h. Using this procedure, $90 \%$ of our repeats per seed (differences between particular measurements and average value per seed expressed in percentage) in the error rate experiment were within the range of $5.33 \%$, which is almost consistent with the very stringent criterion of one of the most routinely applied FCM protocols (2\%, Doležel et al. 2007). The practice commonly used to satisfy this criterion is, however, to discard extreme values and perform repeat measurements. If this practice is not followed, as in the case of small seeds, or all measured data are included in the mean genome size calculation, variation may be as high as $8.2 \%$ (e.g. Escudero et al. 2015). 
Genome size has previously been established for both $O$. pseudoarenaria and $O$. arenaria (5.74 pg and 5.15 pg DNA, respectively) based on leaf material from Central Europe (Mártonfi et al. 2008). These values are very similar to those reported in the present study for leaves (5.83 pg and $5.22 \mathrm{pg}$ ). A further study reported genome sizes of $6.17 \mathrm{pg}$ and $5.7 \mathrm{pg}$ DNA in the leaves of $O$. pseudoarenaria and $O$. arenaria, respectively; however, in this case, the samples originated mainly from Western Europe (Kolarčik et al. 2014). Although our seed-based genome size estimates for $O$. pseudoarenaria and O. arenaria populations (Table 1) are higher than those previously reported, as described above, this can be attributed to the different material used for nuclei isolation. After inspecting mean genome sizes of taxonomic and geographical groups obtained in the present study, we observed that in both species the DNA content is higher in population groups from Dalmatia (Croatia) than the rest of groups (Fig. 7). This pattern could be related to a common factor for both species, e.g. common hybridogeneous origin (see Kolarčik et al. 2014) or a common ecological or evolutionary driver that could lead to an increase in genome size (Zedek et al. 2010; Kang et al. 2015). Certainly, future detailed research is needed in this field. Alternatively, the higher DNA content may be related to certain taxonomic differentiation in western and eastern populations of both groups of taxa within the entire European region. High leaf- and seed-based genome size estimates in populations from Western Europe and Dalmatia may reflect specific evolutionary and systematic relationships. In this regard, certain historical connections between Western European and Dalmatian population have previously been shown, for example in O. echioides (L.) L. (Kolarčik et al. 2010).

If genome size variation is mainly found between taxonomic groups, e.g. subspecies, this may validate their existence with support from other data (molecular or morphological). In the present study, genome size variations indicate the presence of taxonomic differentiation at least within $O$. arenaria in Eastern Europe. Molecular data suggest separation of the 
Western and Eastern groups of $O$. arenaria with a border in Switzerland (Kolarčik et al. 2014), and the present genome size data support a further split of $O$. arenaria in Eastern Europe. Connections between the populations of $O$. arenaria within its entire distribution range are, however, rather poor. The species is distributed very narrowly, and its range has an island-like character with almost all known populations being mutually isolated.

\section{Conclusion}

In this study, we examined genome size variation in two polymorphic and allopolyploid species, O. arenaria and $O$. pseudoarenaria, which are the only representatives of the Heterotricha group of the genus Onosma known in Europe. We had concerns regarding two methodological issues, which were clarified here. Leaf-based genome size estimates may be biased more frequently than seed-based estimates, putatively because of the common presence of secondary metabolites, which may affect DNA staining. Further, stain intercalation into DNA is a relatively slow process, and thus we recommend the adoption of appropriate methodology in which the same prolonged incubation time is applied to all samples. With improved practice, we have determined the genome size in seed samples and revealed mean value differences between populations in both $O$. arenaria and $O$. pseudoarenaria. In both species, populations from Dalmatia have a higher nuclear DNA content compared with conspecific populations from Central Europe, Romania, and other parts of the Balkan Peninsula. This genome size variation suggests a potential taxonomic split of some taxa in the region, which should be further investigated using molecular and morphological approaches.

Onosma arenaria and $O$. pseudoarenaria are complex hybrid taxa with considerable variation in genome size. This characteristic may further influence the evolutionary 
trajectories of the respective populations. Although the taxonomy of the Heterotricha group within its entire distributional range remains controversial, unanswered questions of taxonomical as well as evolutionary cytogenomical relevance in the group and the genus Onosma generally can now be addressed using genome size data.

\section{Acknowledgements}

We are grateful to anonymous reviewers for helpful comments on the manuscript. We would like to thank Editage (www.editage.com) for English language editing. The Ministry of Environment of the Slovak Republic generously provided us with exception from Nature Conservation of Ministry of Environment of the Slovak Republic No. 1210/481/05-5.1, and allowed us to collect plant material in Slovakia. Plant material of $O$. pseudoarenaria subsp. austriaca was obtained from the Botanical Garden of the University of Vienna (HBV) and was collected thanks to permit from "Land Niederösterreich" No. RU5-BE-182/010-2015. Support for this research was provided by the Grant Agency for Science, Bratislava (VEGA, No. 1/0512/15) and by the Internal Research Grant System of PJ Šafárik University in Košice (VVGS-2014-212). Flow cytometry analyses were performed with equipment established with the support of Structural funds from the EU (project NEXO-Network of Excellence in Oncology) under contract No. 007/20092.1/OPVaV.

\section{References}


Angulo, M.B., and Dematteis, M. 2013. Nuclear DNA content in some species of Lessingianthus (Vernonieae, Asteraceae) by flow cytometry. J. Plant Res. 126: 461468. doi:10.1007/s10265-012-0539-x.

Bainard, J.D., and Newmaster, S.G. 2010. Endopolyploidy in Bryophytes: widespread in mosses and absent in liverworts. J. Bot. Article ID 316356. doi:10.1155/2010/316356.

Bainard, J.D., Fazekas, A.J., and Newmaster, S.G. 2010. Methodology significantly affects genome size estimates: quantitative evidence using bryophytes. Cytometry A, 77: 725732. doi:10.1002/cyto.a.20902.

Bainard, J.D., Bainard, L.D., Henry, T.A., Fazekas, A.J., and Newmaster, S.G. 2012. A multivariate analysis of variation in genome size and endoreduplication in angiosperms reveals strong phylogenetic signal and association with phenotypic traits. New Phytol. 196: 1240-1250. doi:10.1111/j.1469-8137.2012.04370.x.

Ball, P.W. 1972. 9. Onosma L. In Flora Europaea. Volume 3: Diapensiaceae to Myoporaceae. Edited by T.G. Tutin, V.H. Heywood, N.A. Burges, D.M. Moore, D.H. Valentine, S.M. Walters, D.A. Webb. Cambridge University Press, Cambridge, UK. pp. 89-94.

Bennett, M.D., and Leitch, I.J. 2012. Angiosperm DNA $C$-values database [online] (release 8.0, Dec. 2012). Available from http://www.kew.org/cvalues/.

Bennett, M.D., Price, H.J., and Johnston, J.S. 2008. Anthocyanin inhibits propidium iodide DNA fluorescence in Euphorbia pulcherrima: Implications for genome size variation and flow cytometry. Ann. Bot. 101: 777-790. doi:10.1093/aob/mcm303.

Biradar, D.P., and Rayburn, A.L. 1994. Flow cytometric probing of chromatin condensation in maize diploid nuclei. New Phytol. 126: 31-35. doi:10.1111/j.14698137.1994.tb07526.x.

Bourbousse, C., Mestiri, I., Zabulon, G., Bourge, M., Formiggini, F., Koini, M.A., Brown, S.C., Fransz, P., Bowler, C., and Barneche, F. 2015. Light signaling controls nuclear 
architecture reorganization during seedling establishment. Proc. Natl. Acad. Sci. U.S.A. 112: 2836-2844. doi:10.1073/pnas.1503512112.

Ceccarelli, M., Sarri, V., Caceres, M.E., and Cionini, P.G. 2011. Intraspecific genotypic diversity in plants. Genome, 54: 701-709. doi:10.1139/g11-039.

Chacón, J., Luebert, F., Hilger, Hartmut H., Ovchinnikova, S., Selvi, F., Cecchi, L., Guilliams, C.M., Hasenstab-Lehman, K., Sutorý, K., Simpson, M.G., and Weigend, M. 2016. The borage family (Boraginaceae s.str.): a revised infrafamilial classification based on new phylogenetic evidence, with emphasis on the placement of some enigmatic genera. Taxon, 65: 523-546. doi:10.12705/653.6.

Chalup, L., Grabiele, M., Neffa, V.S., and Seijo, G. 2014. DNA content in South American endemic species of Lathyrus. J. Plant Res. 127: 469-480. doi:10.1007/s10265-0140637-z.

Cires, E., Cuesta, C., Fernández Casado, M.Á., Nava, H.S., Vázquez, V.M., and Fernández Prieto, J.A. 2011. Isolation of plant nuclei suitable for flow cytometry from species with extremely mucilaginous compounds: an example in the genus Viola L. (Violaceae). Anales Jard. Bot. Madrid, 68: 139-154. doi:10.3989/ajbm.2273.

Dauphin, B., Grant, J., and Mráz, P. 2016. Ploidy level and genome size variation in the homosporous ferns Botrychium s.l. (Ophioglossaceae). Pl. Syst. Evol. 302: 575-584. doi: $10.1007 / \mathrm{s} 00606-016-1285-7$.

Ding, J., Shi, S., Jiang, B-H., Yang, Y-H., Huang, J., Shen, H-G., Xia, K., Zhang, J., and Jiang, X. 2004. Effects of methyl jasmonate with indole-3-acetic acid and 6benzylaminopurine on the secondary metabolism of cultured Onosma paniculatum cells. In Vitro Cell. Dev. Biol. Plant. 40: 581-585. doi:10.1079/IVP2004578. 
Doležel, J., and Göhde, W. 1995. Sex determination in dioecious plants Melandrium album and M. rubrum using high-resolution flow cytometry. Cytometry, 19: 103-106. doi:10.1002/cyto.990190203.

Doležel, J., and Bartoš, J. 2005. Plant DNA flow cytometry and estimation of nuclear genome size. Ann. Bot. 95: 99-110. doi:10.1093/aob/mci005.

Doležel, J., Sgorbati, S., and Lucretti, S. 1992. Comparison of three DNA fluorochromes for flow cytometric estimation of nuclear DNA content in plants. Physiol. Plant. 85: 625631. doi:10.1111/j.1399-3054.1992.tb04764.x.

Doležel, J., Greilhuber, J., and Suda, J. 2007. Estimation of nuclear DNA content in plants using flow cytometry. Nature Protocols, 2: 2233-2244. doi:10.1038/nprot.2007.310.

Escudero, M., Maguilla, E., Loureiro, J., Castro, M., Castro, S., and Luceño, M. 2015. Genome size stability despite high chromosome number variation in Carex gr. laevigata. Am. J. Bot. 102: 233-238. doi:10.3732/ajb.1400433.

Galbraith, D.W., Harkins, K.R., Maddox, J.M., Ayres, N.M., Sharma, D.P., and Firoozabady, E. 1983. Rapid flow cytometric analysis of the cell cycle in intact plant tissues. Science, 220: 1049-1051. doi:10.1126/science.220.4601.1049.

Garcia, S., Leitch, I.J., Anadon-Rosell, A., Canela, M.Á., Gálvez, F., Garnatje, T., Gras, A., Hidalgo, O., Johnston, E., Mas de Xaxars, G., Pellicer, J., Siljak-Yakovlev, S., Vallès, J., Vitales, D., and Bennett, M.D. 2014. Recent updates and developments to plant genome size databases. Nucleic Acids Res. 42: D1159-D1166. doi:10.1093/nar/gkt1195.

Gharib, A., and Godarzee, M. 2016. Determination of secondary metabolites and antioxidant activity of some boraginaceae species growing in Iran. Trop. J. Pharm. Res. 15: 24592465. doi:10.4314/tjpr.v15i11.22. 
Greilhuber, J. 2005. Intraspecific variation in genome size in angiosperms: identifying its existence. Ann. Bot. 95: 91-98. doi:10.1093/aob/mci004.

Greilhuber, J., Temsch, E.M., and Loureiro, J.C.M. 2007. Nuclear DNA content measurement. In Flow cytometry with plant cells: analysis of genes, chromosomes and genomes. Edited by J. Doležel, J. Greilhuber, J. Suda. Wiley-VCH Verlag GmbH \& Co. KGaA, Weinheim, Germany. pp. 67-101.

Hall, S.E., Dvorak, W.S., Johnston, J.S., Price, H.J., and Williams, C.G. 2000. Flow cytometric analysis of DNA content for tropical and temperate New World Pines. Ann. Bot. 86: 1081-1086. doi:10.1006/anbo.2000.1272.

Hanušová, K., Ekrt, L., Vít, P., Kolář, F., and Urfus, T. 2014. Continuous morphological variation correlated with genome size indicates frequent introgressive hybridization among Diphasiastrum species (Lycopodiaceae) in Central Europe. PLoS ONE, 9: e99552. doi:10.1371/journal.pone.0099552.

Hammer, Ø., Harper, D.A.T., and Ryan, P.D. 2001. PAST: Paleontological statistics software package for education and data analysis. Palaeontol. Electron. 4: 9 pp.

Jávorka, S. 1906. Hazai Onosma-fajaink. (Species Hungaricae generis Onosma). Annls Hist.Nat. Mus. Nat. Hung. 4: 406-449.

Jedrzejczyk, I., and Sliwinska, E. 2010. Leaves and seeds as materials for flow cytometric estimation of the genome size of 11 Rosaceae woody species containing DNA-staining inhibitors. J. Bot. Article ID 930895. doi:10.1155/2010/930895.

Judd, W.S., Campbell, C.S., Kellogg, E.A., Stevens, P.F., and Donoghue, M.J. 2016. Plant systematics: a phylogenetic approach. 4th Edition. Sinauer Associates, Inc., Sunderland, Massachusetts, USA.

Kang, M., Wang, J., and Huang, H. 2015. Nitrogen limitation as a driver of genome size evolution in a group of karst plants. Sci. Rep. 5: 11636. doi:10.1038/srep11636. 
Knight, C.A., Molinari, N.A., and Petrov, D.A. 2005. The large genome constraint hypothesis: evolution, ecology and phenotype. Ann. Bot. 95: 177-190. doi:10.1093/aob/mci011.

Kolarčik, V., Zozomová-Lihová, J., and Mártonfi, P. 2010. Systematics and evolutionary history of the Asterotricha group of the genus Onosma (Boraginaceae) in central and southern Europe inferred from AFLP and nrDNA ITS data. Plant Syst. Evol. 290: 2145. doi:10.1007/s00606-010-0346-6.

Kolarčik, V., Zozomová-Lihová, J., Ducár, E., and Mártonfi, P. 2014. Evolutionary significance of hybridization in Onosma (Boraginaceae): analyses of stabilized hemisexual odd polyploids and recent sterile hybrids. Biol. J. Linn. Soc. 112: 89-107. doi: 10.1111/bij.12270.

Kolarčik, V., Ducár, E., and Kačmárová, T. 2015. Patterns of pollen stainability in polyploids of the genus Onosma (Boraginaceae). Plant Ecol. Evol. 148: 76-89. doi: 10.5091/plecevo.2015.1053.

Kumar, N., Kumar, R., and Kishore, K. 2013. Onosma L.: A review of phytochemistry and ethnopharmacology. Pharmacogn. Rev. 7: 140-151. doi:10.4103/0973-7847.120513.

Leitch, I.J., and Bennett, M.D. 2007. Genome size and its uses: the impact of flow cytometry. In Flow cytometry with plant cells: analysis of genes, chromosomes and genomes. Edited by J. Doležel, J. Greilhuber, J. Suda. Wiley-VCH Verlag GmbH \& Co. KGaA, Weinheim, Germany. pp. 153-176.

Leong-Škorničková, J., Šída, O., Jarolímová, V., Sabu, M., Fér, T., Trávníček, P., and Suda, J. 2007. Chromosome numbers and genome size variation in Indian species of Curcuma (Zingiberaceae). Ann. Bot. 100: 505-526. doi: 10.1093/aob/mcm144 
Loureiro, J., Rodriguez, E., Doležel, J., and Santos, C. 2006. Flow cytometric and microscopic analysis of the effect of tannic acid on plant nuclei and estimation of DNA content. Ann. Bot. 98: 515-527. doi:10.1093/aob/mc1140.

Loureiro, J., Rodriguez, E., Doležel, J., and Santos, C. 2007. Two new nuclear isolation buffers for plant DNA flow cytometry: A test with 37 species. Ann. Bot. 100: 875-888. doi:10.1093/aob/mcm152.

Loureiro, J., Trávníček, P., Rauchová, J., Urfus, T., Vit, P., Štech, M., Castro, S., and Suda, J. 2010. The use of flow cytometry in the biosystematics, ecology and population biology of homoploid plants. Preslia, 82: 3-21.

Luque, T. 1990. Karyological studies on Spanish Boraginaceae. V: Onosma L., Cerinthe L. and Alkanna Tausch (Lithospermae). Bot. J. Linn. Soc. 102: 261-272. doi:10.1111/j.1095-8339.1990.tb01880.x.

Mártonfi, P., Mártonfiová, L., and Kolarčik, V. 2008. Karyotypes and genome size of Onosma species from northern limits of the genus in Carpathians. Caryologia, 61: 363374. doi:10.1080/00087114.2008.10589648.

Mazandarani, M., Moghaddam, P.Z., Baiat, H., Zolfaghari, M.R., Ghaemi, E.A., and Hemati, H. 2011. Antioxidant activity, phenol, flavonoid and anthocyanin contents in various extracts of Onosma dichroanthum Boiss. in north of Iran. Iran. J. Plant Physiol. 1: 169176.

Mazandarani, M., Moghaddam, P.Z., Baiat, H., Zolfaghari, M.R., Ghaemi, E.A., and Hemati, H. 2012. Effects of solvent type on phenolics and flavonoids content and antioxidant activities in Onosma dichroanthum Boiss. J. Med. Plants Res. 6: 4481-4488. doi:10.5897/JMPR11.1460.

Meusel, H., Jäger, E., Rauschert, S., and Weinert, E. 1978. Vergleichende chorologie der zentraleuropäischen flora -Karten-Band II. Gustav Fischer Verlag, Jena, Germany. 
Murray, B. 1998. Nuclear DNA amounts in gymnosperms. Ann. Bot. 82 (Supplement A): 315. doi:10.1006/anbo.1998.0764.

Murray, B.G. 2005. When does intraspecific C-value variation become taxonomically significant? Ann. Bot. 95: 119-125. doi:10.1093/aob/mci007.

Naczk, M., Amarowicz, R., Sullivan, A., and Shahidi, F. 1998. Current research developments on polyphenolics of rapeseed/canola: a review. Food Chem. 62: 489-502. doi:10.1016/S0308-8146(97)00198-2.

Noirot, M., Barre, P., Louarn, J., Duperray, Ch., and Hamon S. 2000. Nucleus-cytosol interactions - a source of stoichiometric error in flow cytometric estimation of nuclear DNA content in plants. Ann. Bot. 86: 309-316. doi:10.1006/anbo.2000.1187.

Obermayer, R., Leitch, I.J., Hanson, L., and Bennett, M.D. 2002. Nuclear DNA C-values in 30 Species Double the Familial Representation in Pteridophytes. Ann. Bot. 90: 209-217. doi:10.1093/aob/mcf167.

Otto, F. 2010. DAPI staining of fixed cells for high-resolution flow cytometry of nuclear DNA. In Methods in cell biology. Edited by H. Crissman, Z. Darzynkiewicz. Academic Press, New York, USA. pp. 105-110.

Papageorgiou, V.P., Assimopoulou, A.N., Couladouros, E.A., Hepworth, D., and Nicolaou, K.C. 1999. The chemistry and biology of alkannin, shikonin, and related naphthazarin natural products. Angew. Chem. Int. Ed. 38: 270-300. doi:10.1002/(SICI)15213773(19990201)38:3<270::AID-ANIE270>3.0.CO;2-0.

Pinto, G., Loureiro, J., Lopes, T., and Santos, C. 2004. Analysis of the genetic stability of Eucalyptus globulus Labill. somatic embryos by flow cytometry. Theor. Appl. Genet. 109: 580-587. doi:10.1007/s00122-004-1655-3. 
Price, H.J., Hodnett, G., and Johnston, J.C. 2000. Sunflower (Helianthus annuus) leaves contain compounds that reduce nuclear propidium iodide fluorescence. Ann. Bot. 86: 929-934. doi:10.1006/anbo.2000.1255.

R Core Team. 2016. R: A language and environment for statistical computing. R Foundation for Statistical Computing, Vienna, Austria. Available from https://www.R-project.org/.

Rauschert, S. 1976. Zur nomenklatur und chorologie des formenkreises von Onosma pseudoarenarium Schur s. lat. Folia Geobot. Phytotaxon. 11: 269-279. doi:10.1007/BF02909475.

Šarhanová, P., Vašut, R.J., Dančák, M., Bureš, P., and Trávníček, B. 2012. New insights into the variability of reproduction modes in European populations of Rubus subgen. Rubus: how sexual are polyploid brambles? Sex. Plant Reprod. 25: 319-335. doi: 10.1007/s00497-012-0200-9.

Siljak-Yakovlev, S., Pustahija, F., Šolić, E.M., Bogunić, F., Muratović, E., Bašić, N., Catrice, O., and Brown, S. C. 2010. Towards a genome size and chromosome number database of Balkan flora: C-values in 343 taxa with novel values for 242. Adv. Sci. Lett. 3: 190213. doi.org/10.1166/asl.2010.1115.

Simpson, M.G. 2010. Plant systematics. Academic Press, San Diego, California, USA.

Sliwinska, E., Zielinska, E., and Jedrzejczyk, I. 2005. Are seeds suitable for flow cytometric estimation of plant genome size? Cytometry A, 64: 72-79. doi:10.1002/cyto.a.20122.

Šmarda, P., and Bureš, P. 2006. Intraspecific DNA content variability in Festuca pallens on different geographical scales and ploidy levels. Ann. Bot. 98: 665-678. doi:10.1093/aob/mcl150.

Šmarda, P., and Bureš, P. 2010. Understanding intraspecific variation in genome size in plants. Preslia, 82: 41-61. 
Stuessy, T.F., Crawford, D.J., Soltis, D.E., and Soltis, P.L. 2014. Plant systematics. The origin, interpretation, and ordering of plant biodiversity. Koeltz Scientific Books, Königstein, Germany.

Suda, J. 2004. An employment of flow cytometry into plant biosystematics. PhD thesis, Department of Botany, Charles University, Prague.

Suda, J., Kyncl, T., and Jarolímová, V. 2005. Genome size variation in Macaronesian angiosperms: forty percent of the Canarian endemic flora completed. Plant Syst. Evol. 252: 215-238. doi:10.1007/s00606-004-0280-6.

Suda, J., Krahulcová, A., Trávníček, P., Rosenbaumová, R., Peckert, T., and Krahulec, F. 2007a. Genome size variation and species relationships in Hieracium sub-genus Pilosella (Asteraceae) as inferred by flow cytometry. Ann. Bot. 100(6): 1323-1335. doi:10.1093/aob/mcm218.

Suda, J., Kron, P., Husband, B.C., and Trávniček, P. 2007b. Flow cytometry and ploidy: applications in plant systematics, ecology and evolutionary biology. In Flow cytometry with plant cells: analysis of genes, chromosomes and genomes. Edited by J. Doležel, J. Greilhuber, J. Suda. Wiley-VCH Verlag GmbH \& Co. KGaA, Weinheim, Germany. pp. $103-130$.

Sun, D.Y., Yin, Z.J., Wu, Sh.J., Su, J., Shi, Sh., Wu, H., Xiao, F.H., Qi, J.L., Liu, Zh., Pang, Y.J., Shen, H.G., and Yang, Y.H. 2007. Effects of abscisic acid on the secondary metabolism of cultured Onosma paniculatum cells. Russ. J. Plant Physiol. 54: 530-535. doi:10.1134/S1021443707040152.

Sut, S., Pavela, R., Kolarčik, V., Cappellacci, L., Petrelli, R., Maggi, F., Dall'Acqua, S., and Benelli, G. 2017. Identification of Onosma visianii roots extract and purified shikonin derivatives as potential acaricidal agents against Tetranychus urticae. Molecules, 22: 1002. doi:10.3390/molecules22061002. 
Temsch, E.M., Greilhuber, J., and Krisai, R. 2010. Genome size in liverworts. Preslia, 82: 6380.

Teppner, H. 1971. Cytosystematik, bimodale chromosomensätze und permanente anorthoploidie bei Onosma (Boraginaceae). Österr. bot. Z. 119: 196-233. doi:10.1007/BF01373117.

van Zanten, M., Koini, M.A., Geyer, R., Liu, Y., Brambilla, V., Bartels, D., Koornneef, M., Fransz, P., and Soppe, W.J.J. 2011. Seed maturation in Arabidopsis thaliana is characterized by nuclear size reduction and increased chromatin condensation. Proc. Natl. Acad. Sci. U.S.A.. 108: 20219-20224. doi:10.1073/pnas.1117726108.

Voglmayr, H. 2007. DNA Flow cytometry in non-vascular plants. In Flow cytometry with plant cells: analysis of genes, chromosomes and genomes. Edited by J. Doležel, J. Greilhuber, J. Suda. Wiley-VCH Verlag GmbH \& Co. KGaA, Weinheim, Germany. pp. $267-286$.

Vouillamoz, J. 2001. Approches cytotaxonomique et moléculaire de la phylogéographie des taxons du genre Onosma (Boraginaceae) en Suisse et dans les pays limitrophes. PhD thesis, Faculté des Sciences de l'Université de Lausanne, Lausanne, Switzerland.

Wang, J., Liu, J., and Kang, M. 2015. Quantitative testing of the methodology for genome size estimation in plants using flow cytometry: a case study of the Primulina genus. Front. Plant Sci. 6: 354. doi:10.3389/fpls.2015.00354.

Wickham, H. 2009. ggplot2: Elegant graphics for data analysis. Springer-Verlag, New York, USA.

Wu, S.J., Qi, J.L., Zhang, W.J., Liu, S.H., Xiao, F.H., Zhang, M.S., Xu, G.H., Zhao, W.G., Shi, M.W., Pang, Y.J., Shen, H.G., and Yang, Y.H. 2009. Nitric oxide regulates shikonin formation in suspension-cultured Onosma paniculatum cells. Plant Cell Physiol. 50: 118-128. doi:10.1093/pcp/pen178. 
Zedek, F., Šmerda, J., Šmarda, P., and Bureš, P. 2010. Correlated evolution of LTR retrotransposons and genome size in the genus Eleocharis. BMC Plant Biol. 10: 265. doi:10.1186/1471-2229-10-265.

Zonneveld, B.J.M. 2009. The systematic value of nuclear genome size for "all" species of Tulipa L. (Liliaceae). Plant Syst. Evol. 281: 217-245. doi:10.1007/s00606-009-0203-7.

Zonneveld, B.J.M. 2012a. Conifer genome sizes of 172 species, covering 64 of 67 genera, range from 8 to 72 picogram. Nord. J. Bot. 30: 490-502. doi:10.1111/j.17561051.2012.01516.x.

Zonneveld, B.J.M. 2012b. Genome sizes for all genera of Cycadales. Plant Biol. 14: 253-256. doi:10.1111/j.1438-8677.2011.00522.x. 
1 Table 1. Plant material of five identified and one unidentified taxa of Onosma arenaria and $O$. pseudoarenaria used in the study of genome size 2 data. Population codes, source locality with GPS coordinates, and number of seeds collected from respective number of individuals are given.

3 Two letter ISO (International Organization for Standardization) country codes, BA - Bosnia and Herzegovina, HR - Croatia, ME - Montenegro, 4 were applied to trace geographic origin of particular groups of populations.

\begin{tabular}{|c|c|c|c|c|c|c|}
\hline No. & Taxon & Code & Locality & Coordinates & $\begin{array}{l}\text { No. of seeds/No. of } \\
\text { individuals }\end{array}$ & $\begin{array}{l}\text { Genome size }[2 \mathrm{C} \\
\text { value } \pm \mathrm{SD}(\mathrm{pg})]\end{array}$ \\
\hline & O. arenaria & & & & & \\
\hline 1. & subsp. arenaria & CHIT & Romania, Vadu & $44.45^{\circ} \mathrm{N} / 28.77^{\circ} \mathrm{E}$ & $13 / 4$ & $5.29 \pm 0.17$ \\
\hline 2. & subsp. arenaria & CSK & Hungary, Csákberény & $47.34^{\circ} \mathrm{N} / 18.36^{\circ} \mathrm{E}$ & $11 / 3$ & $5.25 \pm 0.15$ \\
\hline \multirow[t]{3}{*}{3.} & subsp. arenaria & $\mathrm{EPO}$ & Hungary, Epöl & $47.65^{\circ} \mathrm{N} / 18.66^{\circ} \mathrm{E}$ & $25 / 7$ & $5.44 \pm 0.24$ \\
\hline & & & Overall & & $49 / 14$ & $5.36 \pm 0.22$ \\
\hline & & & (Central Europe + Ron & & & \\
\hline 4. & subsp. arenaria & ARZ & Croatia, Aržano & $43.57^{\circ} \mathrm{N} / 16.98^{\circ} \mathrm{E}$ & $10 / 3$ & $5.82 \pm 0.23$ \\
\hline \multirow[t]{3}{*}{5.} & subsp. arenaria & SUT & Croatia, Sutina & $43.70^{\circ} \mathrm{N} / 16.55^{\circ} \mathrm{E}$ & $11 / 1$ & $5.71 \pm 0.14$ \\
\hline & & & Overall & & $21 / 4$ & $5.76 \pm 0.19$ \\
\hline & & & (Balkan Peninsula) & & & \\
\hline
\end{tabular}




\section{O. pseudoarenaria}

\begin{tabular}{|c|c|c|c|c|c|c|}
\hline 6. & subsp. austriaca & DURNS & Austria, Dürnstein & $48.40^{\circ} \mathrm{N} / 15.52^{\circ} \mathrm{E}$ & $10 / 4$ & $5.98 \pm 0.06$ \\
\hline 7. & subsp. fallax & BRL & Croatia, Jezero Brljan & $44.02^{\circ} \mathrm{N} / 16.03^{\circ} \mathrm{E}$ & $8 / 3$ & $6.39 \pm 0.14$ \\
\hline 8. & subsp. fallax & ERV & Croatia, Ervenik & $44.13^{\circ} \mathrm{N} / 15.91^{\circ} \mathrm{E}$ & $23 / 3$ & $6.53 \pm 0.31$ \\
\hline 9. & subsp. fallax & KNPL & Croatia, Kninsko Polje & $44.06^{\circ} \mathrm{N} / 16.23^{\circ} \mathrm{E}$ & $7 / 2$ & $6.63 \pm 0.36$ \\
\hline 10. & subsp. fallax & $\mathrm{OBC}$ & Croatia, Obruč & $44.08^{\circ} \mathrm{N} / 15.94^{\circ} \mathrm{E}$ & $41 / 7$ & $6.63 \pm 0.28$ \\
\hline & & & $\begin{array}{l}\text { Overall } \\
(\mathrm{HR})\end{array}$ & & $79 / 15$ & $6.58 \pm 0.29$ \\
\hline 11. & subsp. fallax & NIKS & Montenegro, Nikšić & $42.72^{\circ} \mathrm{N} / 19.13^{\circ} \mathrm{E}$ & $24 / 4$ & $6.29 \pm 0.16$ \\
\hline 12. & subsp. fallax & PIP & Montenegro, Piperi & $42.55^{\circ} \mathrm{N} / 19.25^{\circ} \mathrm{E}$ & $30 / 4$ & $6.31 \pm 0.20$ \\
\hline 13. & subsp. fallax & POC & $\begin{array}{l}\text { Bosnia and Herzegovina, } \\
\text { Počitelj }\end{array}$ & $43.17^{\circ} \mathrm{N} / 17.79^{\circ} \mathrm{E}$ & $24 / 6$ & $6.34 \pm 0.25$ \\
\hline 14. & subsp. fallax & PODG & Montenegro, Podgorica & $42.40^{\circ} \mathrm{N} / 19.25^{\circ} \mathrm{E}$ & $19 / 5$ & $6.31 \pm 0.33$ \\
\hline & & & $\begin{array}{l}\text { Overall } \\
(\mathrm{BA}+\mathrm{ME})\end{array}$ & & $97 / 19$ & $6.31 \pm 0.23$ \\
\hline
\end{tabular}


15. subsp

pseudoarenaria

16. subsp.

pseudoarenaria

17. subsp. tuberculata

ORK

Hungary, Örkény

Slovakia, Ladmovce

Overall

ALE

Serbia, Subotinac

subspecies

18. subsp. tuberculata

LADM $46.22^{\circ} \mathrm{N} / 23.57^{\circ} \mathrm{E}$

$27 / 5$

$6.30 \pm 0.14$
$52 / 10$

$32 / 8$

$26 / 5$

$58 / 13$

$22 / 4$
$6.38 \pm 0.16$

$6.34 \pm 0.15$

$6.16 \pm 0.22$

$6.23 \pm 0.22$

$6.19 \pm 0.22$

$6.21 \pm 0.15$ 
6 Table 2. Summary of the results of a inhibition test. Studied populations (Code, see Table 1)

7 and type of material (Leaf vs. Seed) are indicated with number of cases for the particular

8 results of the test.

\begin{tabular}{|c|c|c|c|c|c|}
\hline Code & Material & No effect & $\begin{array}{l}\text { Inhibition } \\
\text { effect }\end{array}$ & $\begin{array}{l}\text { Promotion } \\
\text { effect }\end{array}$ & $\begin{array}{l}\text { Weak } \\
\text { promotion } \\
\text { effect }^{*}\end{array}$ \\
\hline \multirow[t]{2}{*}{ ALE } & leaf & 2 & - & - & - \\
\hline & seed & 3 & - & - & - \\
\hline \multirow[t]{2}{*}{ CHIT } & leaf & 1 & - & 1 & - \\
\hline & seed & 3 & - & - & - \\
\hline \multirow[t]{2}{*}{ CSK } & leaf & - & - & 2 & 1 \\
\hline & seed & 2 & 1 & - & - \\
\hline \multirow[t]{2}{*}{ EPO } & leaf & 1 & - & 1 & 1 \\
\hline & seed & 2 & 1 & 2 & - \\
\hline \multirow[t]{2}{*}{ KNPOL } & leaf & - & - & 2 & 1 \\
\hline & seed & 3 & - & - & - \\
\hline \multirow[t]{2}{*}{ LADM } & leaf & 1 & - & 2 & - \\
\hline & seed & 4 & - & - & - \\
\hline OBC & leaf & - & - & 1 & 1 \\
\hline
\end{tabular}




$\begin{array}{lccccc} & \text { seed } & 3 & - & - & - \\ \text { ORK } & \text { leaf } & 2 & - & - & - \\ & \text { seed } & 1 & 1 & - & 1 \\ \text { PAU } & \text { leaf } & - & - & - & 2 \\ & \text { seed } & 3 & - & - & - \\ \text { SUM }(\mathrm{n}= & \text { Leaf } & 7 & - & 9 & 6\end{array}$

$\begin{array}{lllll}\text { Seed } & 24 & 3 & 2 & 1\end{array}$

12

21 Fig. 2. Representative flow cytometry histograms documenting the inhibition tests. The grey 22 line represents the flow cytometry histogram of samples containing an internal reference 
standard (IRS) and Onosma sample (A sample, see the Materials and Methods section), whereas the black line represents the same sample with an additional externally added IRS (IRSex, A+B sample).

Fig. 3. Incubation period effect on genome size increase in Onosma samples. (A) Relative genome size of seed-based FCM measurements expressed as a percentage increase in genome size after 90-, 150-, and 270-min staining incubations in comparison with the relative genome size recorded after a 30-min staining incubation. Full dot and error bars represent mean $\pm \mathrm{SE}$ values; $N=3$ (OBRUC), $N=4$ (EPO, LADM, ORK), $N=8$ (PAU). (B) Relative genome size difference between subsequent incubation periods. Different lower case letters indicate statisticaly homogeneous groups as determined by the Tukey's pairwise post-hoc test ( $p<$ $0.05)$

Fig. 4. Stochastical measurement error of the flow cytometer. (A) Genome size variation of 27 seeds repeatedly measured on three different days, (B) error rate expressed as the percentage deviation of particular measurements from the "ideal" average value.

Fig. 5. Genome size difference in Onosma species between FCM data obtained from leaf vs. seed samples. Full dot and error bars represent mean \pm SD values.

Fig. 6. Examples of flow cytometry histograms. The calculated genome size is given as a $2 \mathrm{C}$ value. (A, B, C, D and E) Single seed measurements with internal reference standard (IRS) Solanum pseudocapsicum. (F) The presence of a double peak indicates the real genome size variation between two simultaneously prepared and measured seeds (from populations ALE 
47 and OBRUC) with IRS S. pseudocapsicum. Note that in (F) the genome size values were 48 calculated based on separate measurements of particular OBRUC and ALE seeds.

49

50 Fig. 7. Genome size variation of eight groups recognized based on present flow cytometry 51 seed measurements $(N=388)$. Outliers are shown with black dots and mean values are 52 depicted with white dots. For clarity, the geographic origin of samples is indicated in 53 parentheses by two letter ISO (International Organization for Standardization) country codes, 54 BA - Bosnia and Herzegovina, HR - Croatia, ME - Montenegro, RS - Serbia. Different 55 lower case letters indicate statisticaly homogeneous groups as determined by the Mann56 Whitney pairwise post-hoc test $(p<0.05)$.

57 


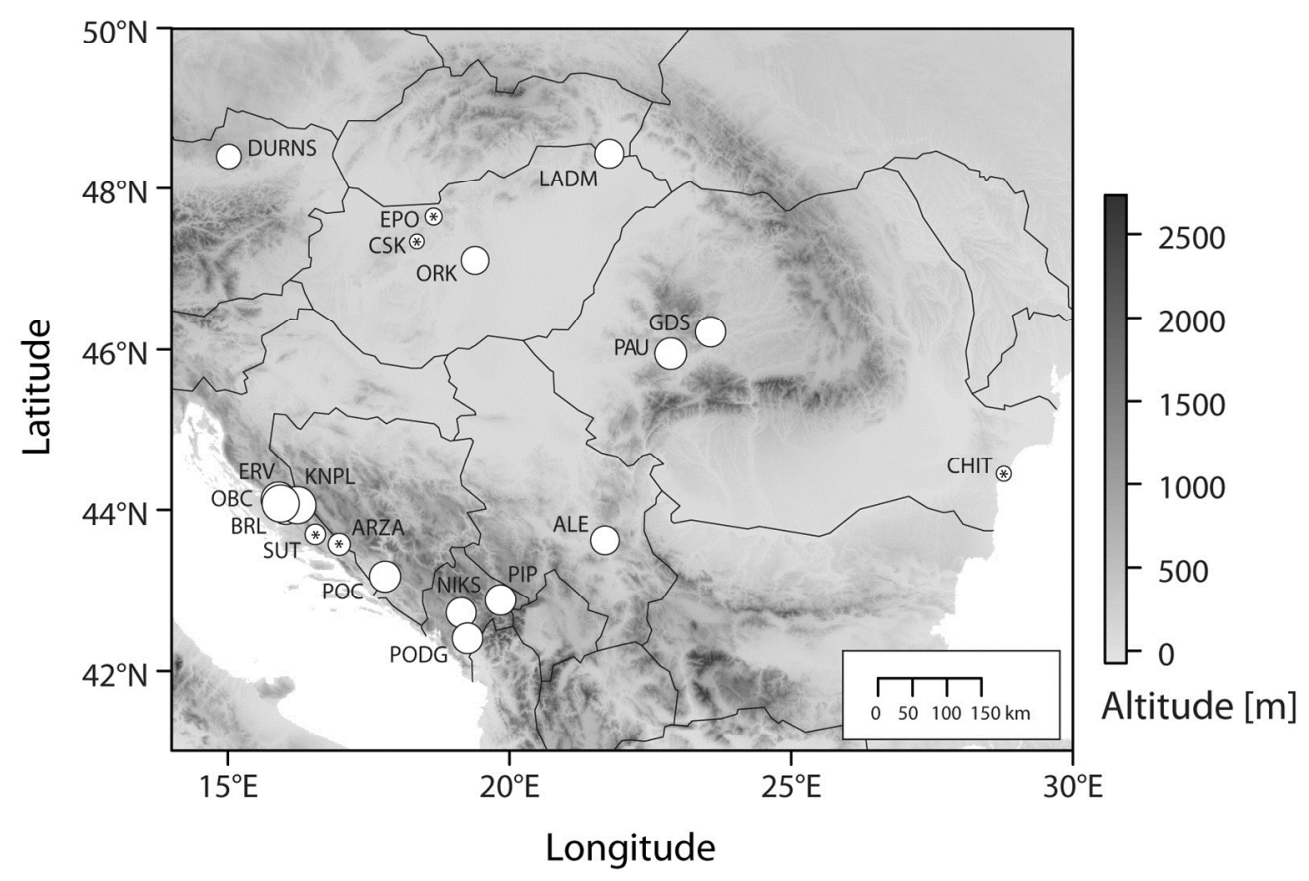

Figure 1.

$138 \times 102 \mathrm{~mm}(300 \times 300 \mathrm{DPI})$ 

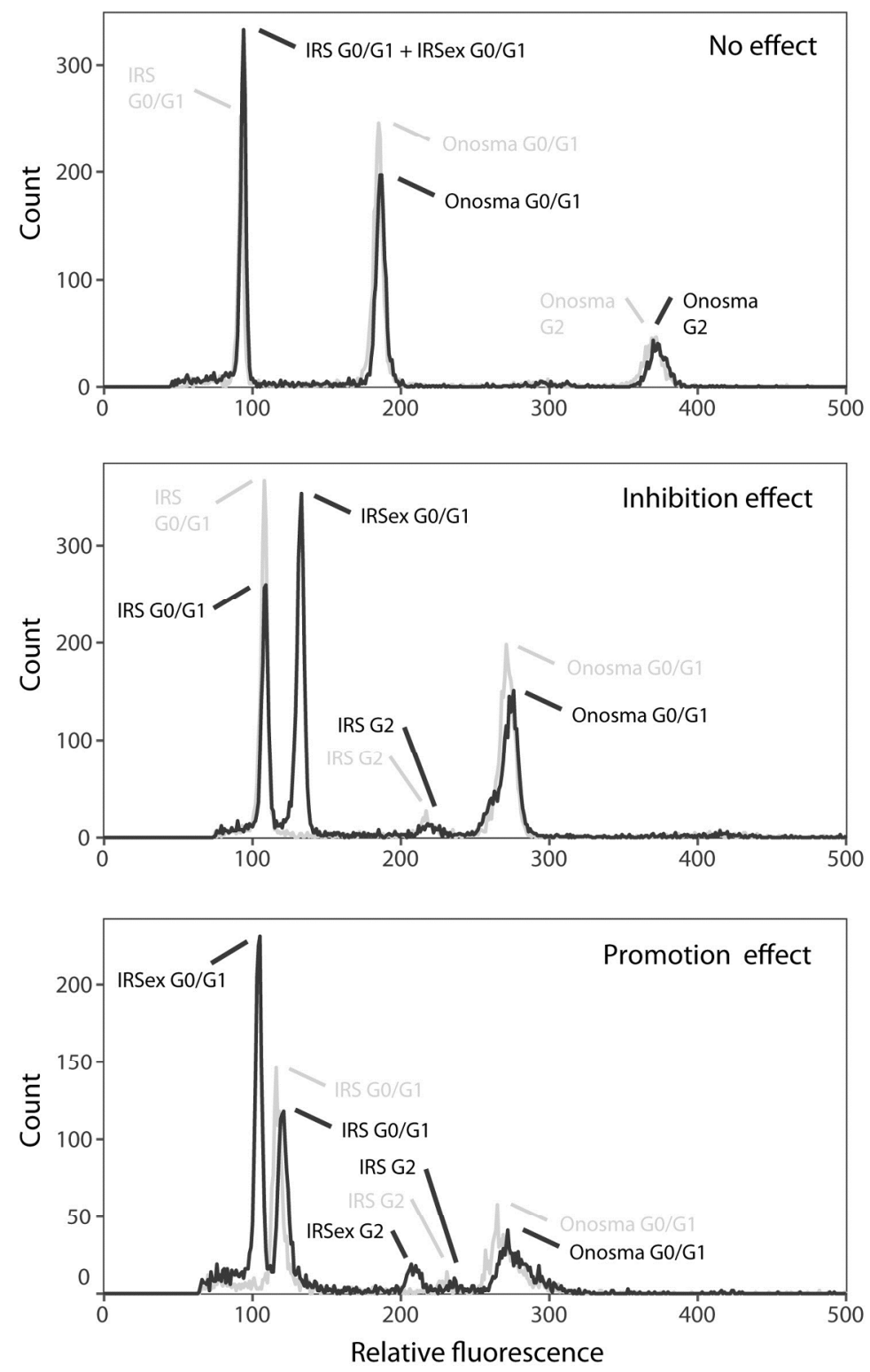

Figure 2.

$128 \times 203 \mathrm{~mm}(300 \times 300$ DPI $)$ 
A

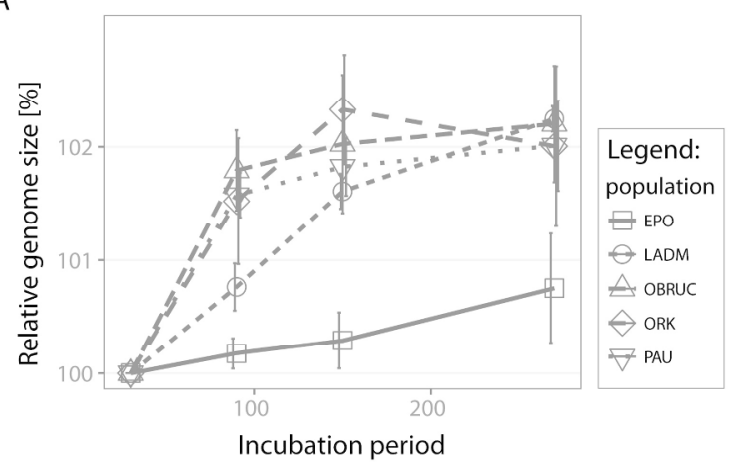

B

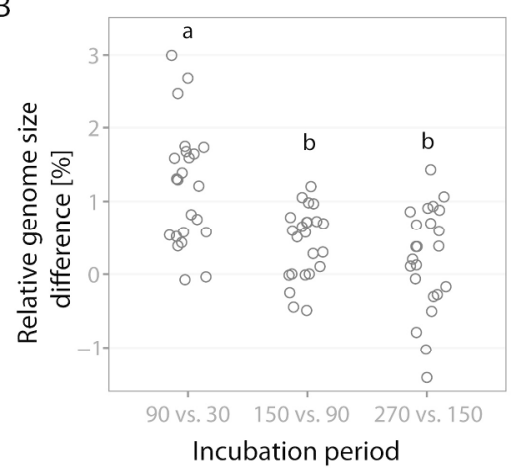

Figure 3.

$231 \times 86 \mathrm{~mm}(300 \times 300 \mathrm{DPI})$ 
A

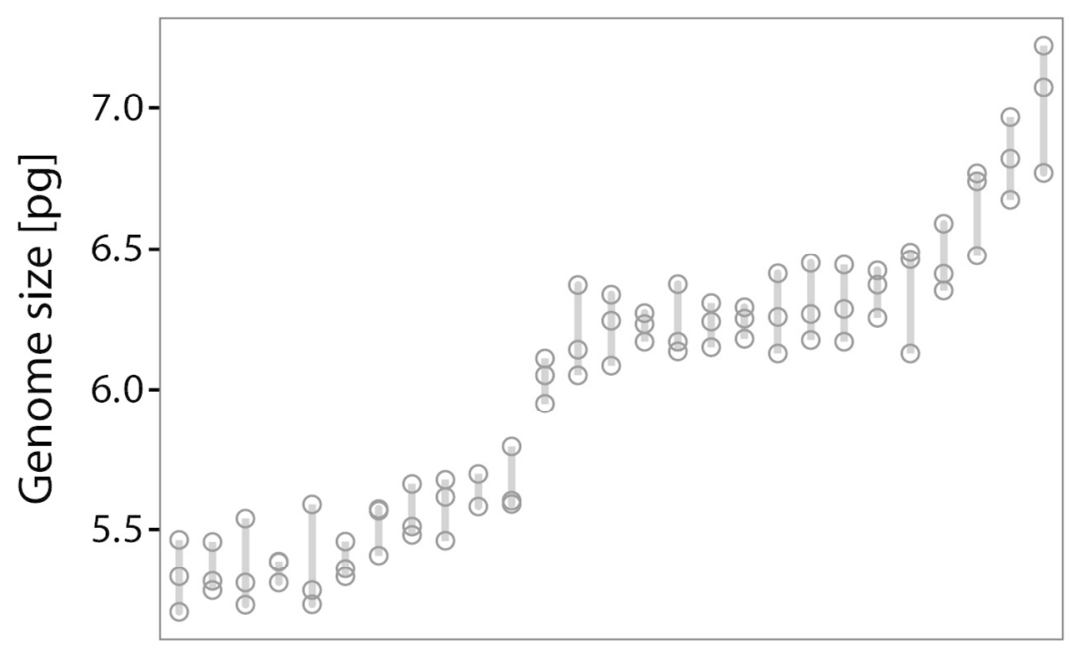

Individual seeds

B

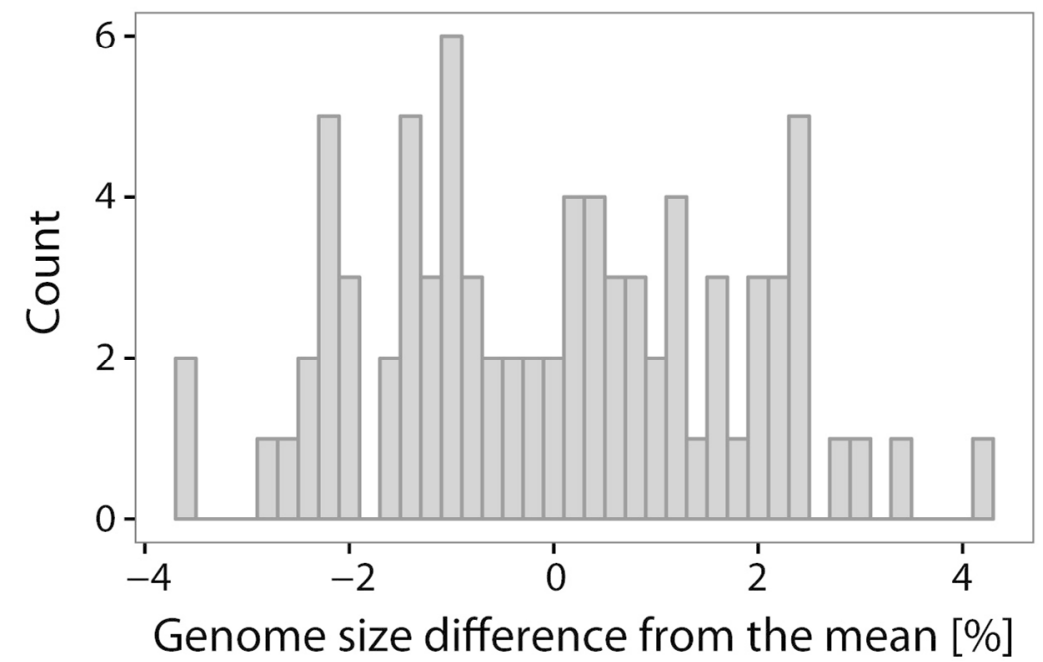

Figure 4.

$117 \times 158 \mathrm{~mm}(300 \times 300$ DPI) 

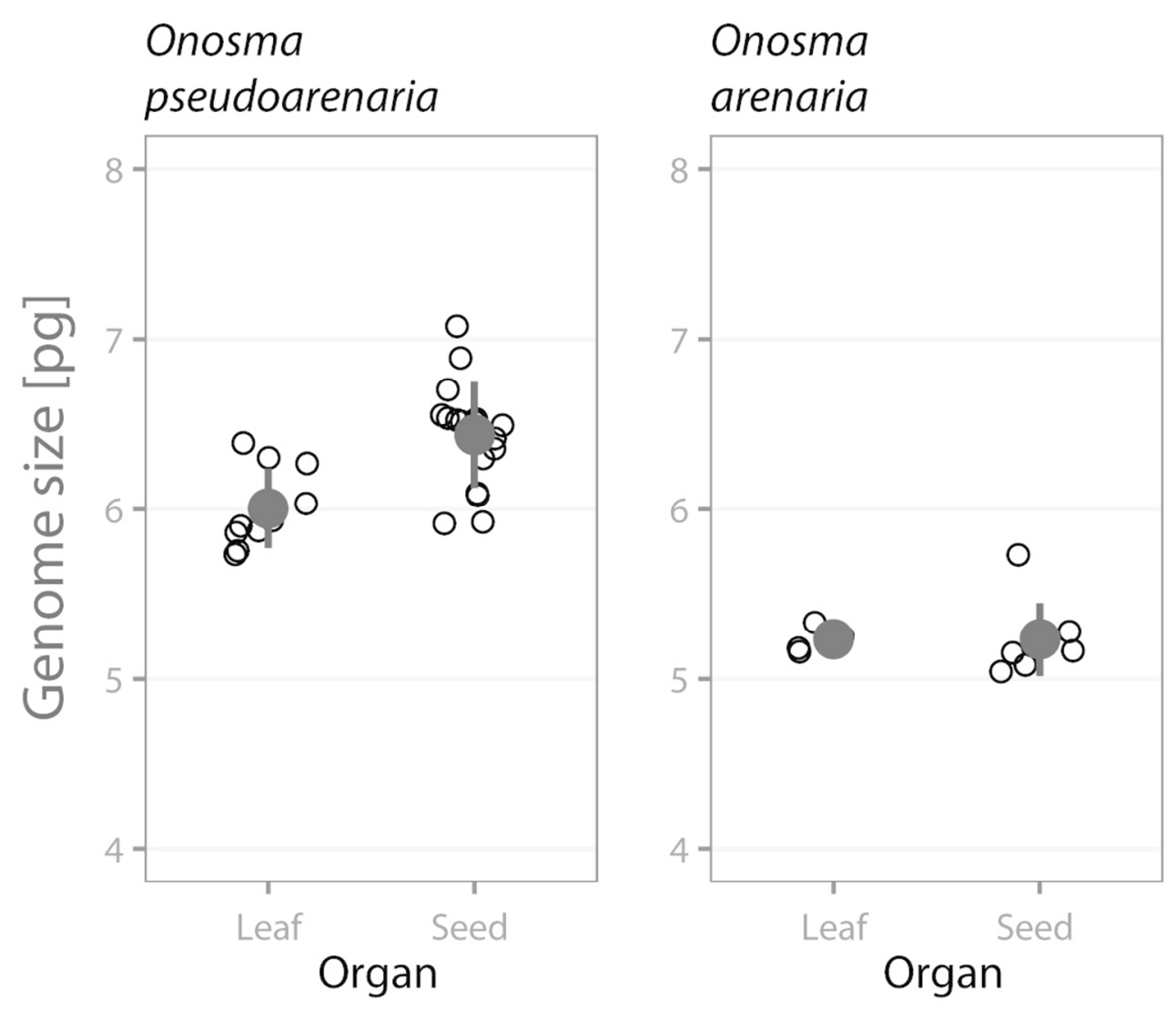

Figure 5.

$98 \times 83 \mathrm{~mm}(300 \times 300$ DPI $)$ 

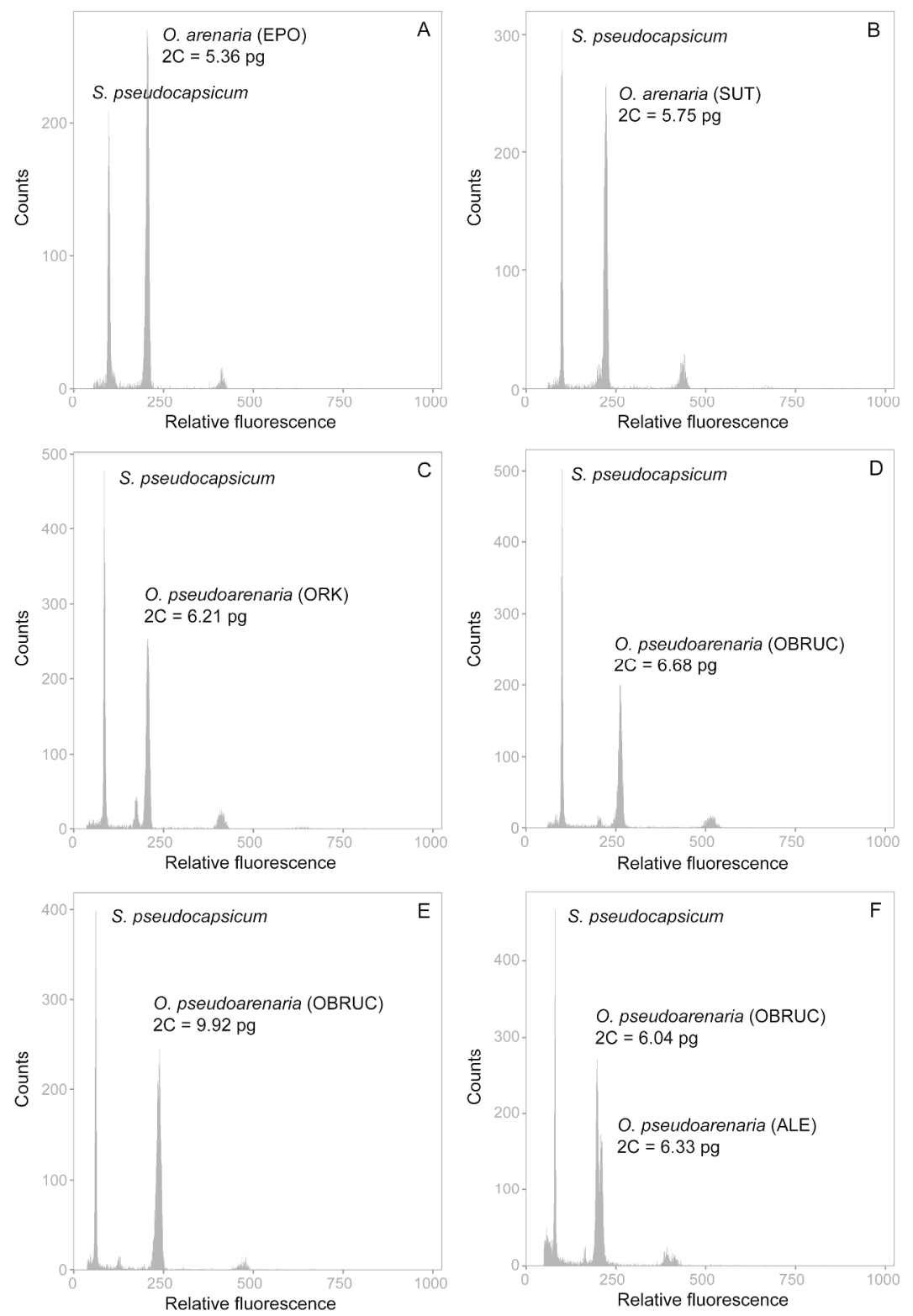

Figure 6.

$245 \times 361 \mathrm{~mm}(300 \times 300 \mathrm{DPI})$

https://mc06.manuscriptcentral.com/botany-pubs 


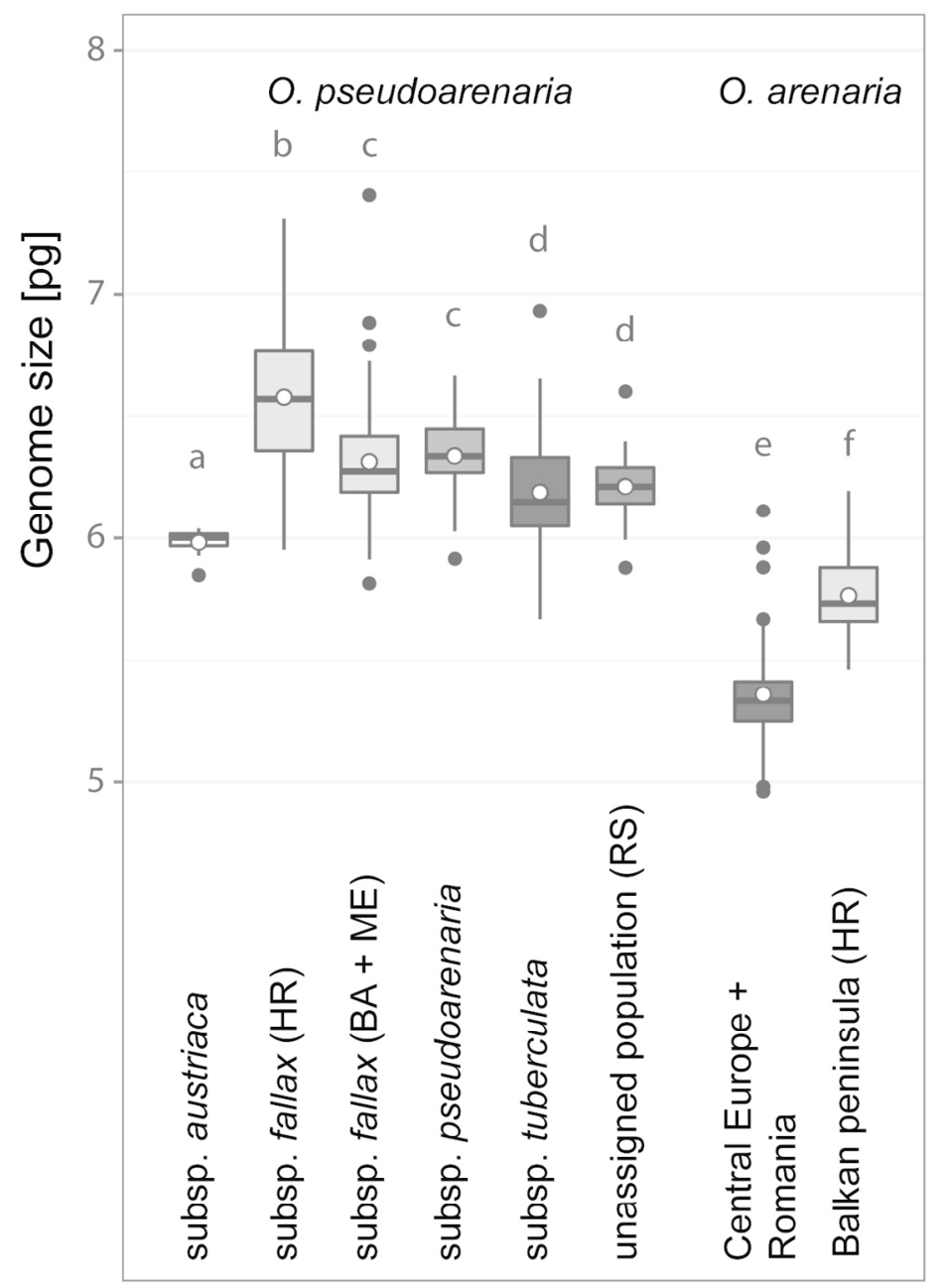

Legend:

$\circ$ mean

- median

25\%-75\% interquartile range (IQR) $\pm 1.5 \times$ IQR

- outliers

Figure 7.

$106 \times 177 \mathrm{~mm}(300 \times 300 \mathrm{DPI})$ 